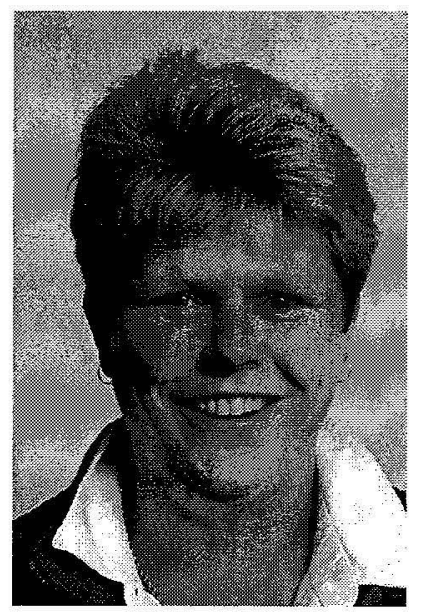

\title{
MODERN APPRENTICESHIP: WHAT'S IN A NAME?
}

\author{
Nicky Murray \\ Environment, Society and Design \\ Division \\ Lincoln University
}

\begin{abstract}
This paper discusses the Modern Apprenticeships programme, introduced by the Labour/Alliance government in 2000. This research forms part of a wider PhD project; an examination of industry training in New Zealand. The research is based upon content analysis of official papers and semi-structured interviews with industry training stakeholders in each of four case study industries: electrical; engineering; hairdressing and agriculture. The research is also informed by understandings gained from my masters thesis, A History of Apprenticeship in New Zealand (2001). To set the Modern Apprenticeships policy in context, this paper first sketches the current industry training situation. Second, the economic, social and political background to the policy is examined. Third, the details of Modern Apprenticeship are outlined, and a critique of some of its facets is offered.
\end{abstract}

\section{Introduction}

This paper discusses the Modern Apprenticeships programme, introduced by the Labour/Alliance government in 2000. This research forms part of a wider $\mathrm{PhD}$ project; an examination of industry training in New Zealand. The research is based upon content analysis of official papers and semi-structured interviews with industry training stakeholders in each of four case study industries: electrical; engineering; hairdressing and agriculture. The research is also informed by understandings gained from my masters thesis, A History of Apprenticeship in New Zealand (2001). To set the Modern Apprenticeships policy in context, this paper first sketches the current industry training situation. Second, the economic, social and political background to the policy is examined. Third, the details of Modern Apprenticeship are outlined, and a critique of some of its facets is offered.

Industry training is a crucial component of the wealthgenerating capabilities of New Zealand. The oft-repeated call for New Zealand to become a 'high-skill' society is part of an emerging international consensus that education and training systems are the key item in the struggle for competitive superiority (Ashton \& Green, 1996). An effective and efficient training system must be responsive to the needs of industry, but at the same time must be able to take account of long term issues that are often beyond the scope of individual firms.

Industry training also has a social role. Various governments have held differing views on the use of industry training to achieve wider objectives than merely providing a skilled work force. Initiatives based on correcting gender, ethnic or regional disparities have found favour at different times. Industry training is also an essential part of the way that many young people, traditionally male, make the transition from school to work and from adolescence to adulthood. Good transition systems are therefore held to be crucial for both the economic and social well-being of any country (Skill New Zealand, 2000a).

The means of training tradespeople has moved over the years from the admittedly rigid and prescriptive apprenticeship system, to the more voluntaristic, industryled 'industry training' strategy. Regardless of the system used to organise training, however, there have been longstanding problems in New Zealand with achieving the optimum number of skilled workers, possessing the correct 'mix' of skills required. One of the main reasons for this is that New Zealand, despite much rhetoric, remains essentially a 'just-enough' skill society. Workplace-based training is, ipso facto, dependent on the decisions of employers, and the level of such training has been historically intimately connected with the cyclic nature of the economy.

\section{The Industry Training Strategy}

The institution of apprenticeship was, for many years, the main route for entry into the skilled trades in New Zealand. The apprenticeship system proved to be remarkably resilient over the years, suiting (albeit for 
different reasons) both employer and apprentice, and becoming an integral part of New Zealand labour relations. During the 1970 s and 1980 s, however, economic, social and political changes challenged the basis for apprenticeship. The length of time taken to train and the fixed nature of the skills taught were seen as barriers to responsiveness to industry demands. Technological changes and the reality of increasing skill levels in some occupations, and the deskilling of others, highlighted rigidities in the apprenticeship system.
The Fourth Labour government, using the mechanisms provided by the Apprenticeship Act 1983, attempted to move the apprenticeship system to assessment based on competency, rather than the time served. By the late 1980 s, however, the contraction of the manufacturing sector, growing unemployment and changes in the wider education sector led to a severe decline in the number of apprentices (see Figure 1). The apprenticeship 'problem' became not one of reforming the system, but of questioning the whole validity of apprenticeship as a means of training.

Figure 1: Apprentice Numbers, 1984-1993 (Department of Labour, 1984-1993)

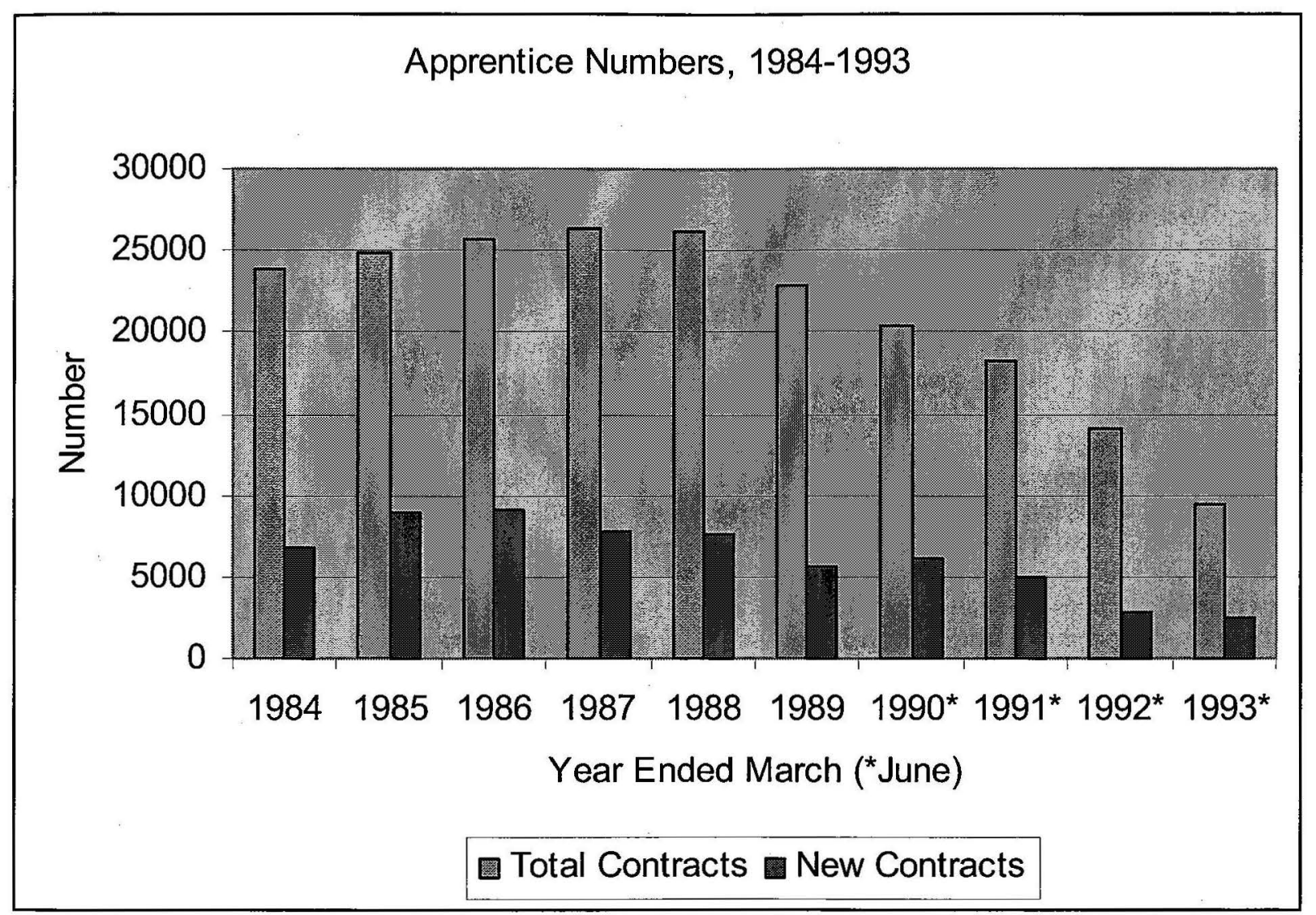

Many of the reforms to post compulsory education suggested during the myriad reviews carried out during the 1980 s were enacted by the 1990 National government. The National government's Industry Skills Training Strategy was announced in the 1991 budget. The new training system was to be industry-led, with Industry Training Organisations (ITOs) to be set up for each industry or group of industries. The development and monitoring of training standards became the function of the New Zealand Qualifications Authority through a system of unit standards. Industry training was administered by the Education and Training Support Agency (renamed Skill New Zealand in 1998) under the Industry Training Act 1992. Apprenticeship contracts were replaced by a Training Agreement between each employer and apprentice, with wages and conditions determined according to the Employment Contracts Act
1991. ITOs were gradually established from 1991 for both traditional apprenticeship industries, and other industries that could see the advantage of systematic training.

The Industry Training strategy has been successful in achieving one of its major aims, which was to extend the benefits of structured training to industries outside of the traditional apprenticeship industries. As at December 2000 , approximately 70 per cent of trainees were registered in programmes that were unrelated to past apprenticeship training (Skill New Zealand, 2001b). The number of industry trainees increased steadily from 1993. Over 78,000 people were involved in some form of industry training as at June 2002 (see Figure 2) (Skill New Zealand, 2002d). 
Figure 2: Numbers in Structured Industry Training, 1993-2002 (Skill New Zealand, 1998; Skill New Zealand, 2002b; 2002e).

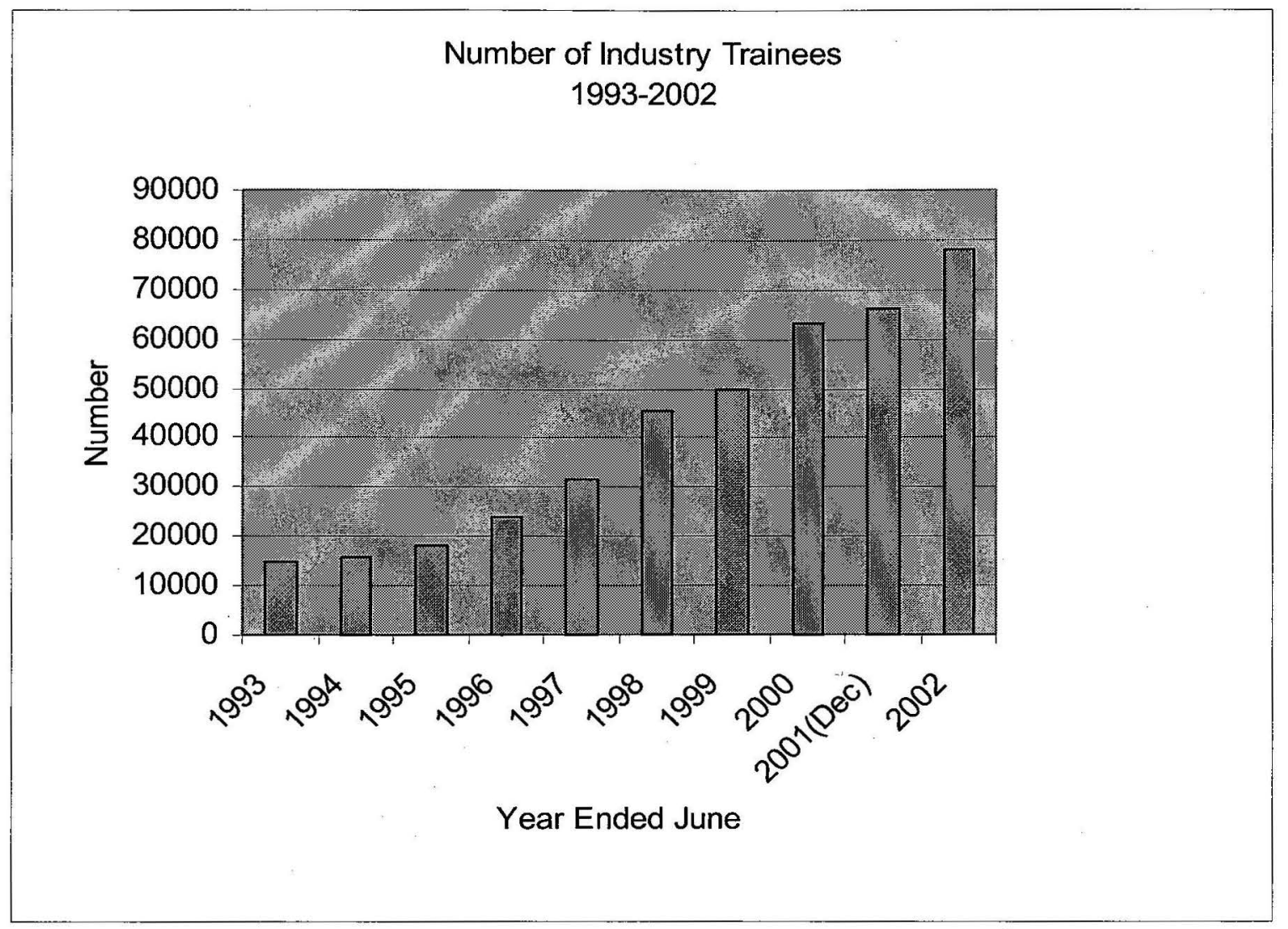

While the ethos of apprenticeship ensured that some employers continued to have a commitment to taking on young people and training them, several of the cornerstones of the traditional apprenticeship system were shattered by the new strategy. One of the most crucial changes to take place was the replacement of the apprenticeship contract with a training contract under the terms of the Employment Contracts Act 1991. The Act placed the onus for negotiating the 'employment contract' on to the individual, breaking "the historical link between union membership and negotiating authority" and "withdraw(ing) the state from its century-old involvement in the extensive prescription of bargaining and representation" (Walsh \& Brosnan, 1999, pp.119-121). Thus, the triumvirate of union, employer and state that had helped protect and support the apprenticeship system was broken.

The new system also enabled the completion of the move to competency-based assessment via the National Qualifications Framework, and facilitated new forms of delivery of the theoretical component of training, such as pre-apprenticeship courses. Perhaps the most significant change, however, was the loss of the term 'apprenticeship'. The perception was created in the minds of many that, because the old structure had been dismantled, there was no longer any such thing as apprenticeship. ${ }^{1}$

\section{Concerns about the Industry Training Strategy}

\section{Funding}

The funding of industry training was problematic. Some of the difficulties identified included: historically-based variations in funding for different ITOs; anomalies between funding for industry training and other tertiary funding (leading in some cases to 'perverse incentives' creating "duplication and competition between ITOs and providers" (Industry Training Federation, 2001, p.8); and ongoing problems with establishing the appropriate balance of industry and government contribution, complicated by the difficulty in assessing the 'in kind' contribution made by industry. Two other issues were the capping of funding for training above Level 4 on the

\footnotetext{
1 This is confirmed by several of my interviewees who were involved in the transition process, and by the oft-repeated comment: "but isn't apprenticeship dead?"
} 
qualifications framework, and the thorny issue of industry levies $^{2}$ (Industry Training Federation, 2001).

The contestable nature of government funding led to inconsistencies in the formation of ITOs. The NZCTU had argued in 1993 that the ability of ITOs to "selfdefine' could lead to duplication of coverage, fragmentation of logical industry groupings, added expense for employers and providers and difficulties with the portability of qualifications (New Zealand Council of Trade Unions, 1993). Some of these fears were borne out with a proliferation of ITOs across some industry sectors, yet no coverage in other sectors (Piercy, 2002).

\section{Organisation}

Funding issues further impacted on the delivery of off-job training. As trainee numbers increased, often without commensurate increases in government funding, some industries revised their long-term training structures to reduce formal polytechnic training to a minimum ("Building industry training at risk, say polytechs," 1998; Gault, 1998). The cut-backs in training by some ITOs caused polytechnics to devise measures to ensure their survival as deliverers of trade training. One of these measures was the fierce marketing of trade courses, with polytechnics prepared to move out of their traditional catchments to entice both students and ITO funding. The training market was also opened to Private Training Establishments (PTEs), leading to some valuable initiatives, but also, arguably, to variations in the quality of training provided ${ }^{3}$.

The development of the National Qualifications Framework (NQF) required a huge amount of effort from government agencies, education providers and industry bodies. Although many trade qualifications were moved wholesale to the NQF, the specificity and detail required to allow competency-based assessment via unit standards meant that each skill had to be broken down into its constituent parts, and written up as a discrete task. Much of the work was done against a background of tight economic conditions and in the competitive environment described previously. Despite the relatively quick transition to the NQF, the complexity of the framework and the increased administrative burden associated with it were disincentives to many employers, (especially those with small businesses), to engage in training.

Another indicator that highlighted growing concerns with industry training was the increasingly vociferous claims of skill shortages in many areas. Skill shortages were identified, for example, in the main centres in 1995 (Shelton, 1995), in the telecommunications industry in 1996 (Rubens, 1996), and in the retail, small engineering and manufacturing, clothing and building trades in 1997

\footnotetext{
${ }^{2}$ An attempt was made to address some of these issues in the 2001 Industry Training Review (Skill New Zealand, 2001d).

${ }^{3}$ The government, in response to funding and quality issues, announced a moratorium on new and existing PTEs in 2001 (Rushworth, 2001).
}

(Henderson, 1997). The December 1999 Quarterly Survey of Business, conducted by the NZIER, found that 35 per cent of firms were finding it more difficult than previously to find skilled labour (Skill New Zealand, 2000b).

\section{Equity Issues}

While the increasing numbers taking part in structured industry training were encouraging, there remained areas of concern. Women remained substantially underrepresented in industry training. Several long-standing trends helped account for this (National Advisory Council on the Employment of Women, 1994). First, women were over-represented in both part-time and casual work. Secondly, many were employed in the service sector, which had less developed systematic training arrangements. Thirdly, two of the areas where women's employment was concentrated, the health and education sectors, although well catered for with tertiary education, did not have industry training organisation coverage. As at June 2002, although women represented 47 per cent of the labour force, only 23 per cent of industry trainees were women (Skill New Zealand, 2002a). This figure included women in the 'traditional' hairdressing industry.

In 2001, Maori made up 17 per cent of all industry trainees, compared with 11 per cent in June 1996 (Skill New Zealand, 2001b; 2002e). Despite the relatively high participation level (Maori comprised approximately ten per cent of the workforce), Maori trainees were concentrated in a small number of industries, notably seafood and forestry (Department of Labour, 2001). The proportion of Pacific Island peoples in industry training rose to 5 per cent in 2001 from 2 per cent in June 1996 (Skill New Zealand, 2001b; 2002e).

The relatively low numbers of young people taking part in structured industry training was of particular concern, especially in light of high rates of youth unemployment. In December 2001, the unemployment rate for those aged fifteen to nineteen was 14.8 per cent $(23,500$ young people), compared with a total unemployment rate of 5.2 percent (Department of Statistics, 2002). In 2001, only 8.5 per cent of industry trainees were aged 15 to 19 , and over 50 per cent were aged 30 years and over (Skill New Zealand, 2002b).These figures reflected several wider trends, such as the increasing emphasis on tertiary education, the loss of significant numbers of apprenticeship positions with the restructuring and privatisation of government departments from the late 1980 s, and the marked decline in the traditional apprenticeship industries (Higgins \& Dalziel, 2002).

Thus, while the Industry Training Strategy had many successes, notably in increasing the numbers involved in industry training, there were problems with funding and with the delivery of off-job training. There were also gaps in coverage, and equity issues. And as the economy began to strengthen in the late $1990 \mathrm{~s}$, skill shortages became apparent in many areas, exposing where training had been neglected or had disappeared altogether. 


\section{Modern Apprenticeships}

\section{Background to Policy Development}

The weaknesses and gaps in industry training were recognised by a revitalised Labour party in the build-up to the 1999 election. Piercy (2002) traced the effect of the union movement on the development of Labour's training strategy. The New Zealand Engineers' Union, influenced through the late 1980s and early 1990s by its Australian counterpart, had become increasingly cognisant of the need to eschew wage militancy in favour of an emphasis on flexible work practices and the upskilling of its members. Education and training thus became a major strategy of the both the Engineers' Union and the New Zealand Council of Trade Unions (NZCTU). Despite the decimation of the union movement by the Employment Contracts Act 1991 and the effective marginalisation of the union viewpoint by the National government, the union movement continued to argue, in publications such as Building better skills (1993), for a "high-skilled, high waged economy...based on a general increase in jobs and skills" (New Zealand Council of Trade Unions (NZCTU), 1993, p.4). Increasingly side-lined by the ideologicallydriven National government, the union movement shifted its focus to the more receptive Labour Party (Piercy, 2002).

The Labour Party in the late 1990s had "sharpened its understanding of the limitations of [the] facilitative, voluntarist model [of industry training] and was more inclined to a legislative, semi-regulatory approach coupled with a more pronounced...notion of partnership" (Piercy, 2002, p.9). The emerging rhetoric was that of the 'third way'; a social democratic bridle thrown over the capitalist stallion, harnessing the energy, but allowing some direction to be given and the excesses to be reinedin. 'Third way' ideas were placed in the New Zealand context in The new politics: The third way in New Zealand (1999), co-authored by union and academic writers with close links to the Labour Party (Piercy, 2002). Thus, Labour's training strategy prior to the 1999 election, spelled out in $21^{\text {st }}$ Century Skills (1999), was couched in terms of both a high-skill, high-wage economy, and of a more hands-on role for government. The strategy was clearly designed to reinvigorate Labour's standing among one of its most important traditional bases, the trade union movement:

A Labour Government will forge a new compact with workers. We will guarantee that workers will receive the best possible education and training at the start of their working lives and have the ability to upskill and retrain throughout life (Labour Party, 1999)

Labour's training strategy signposted greater contiguity between school and work, with, for example, an expanded careers service, and the Gateway programme, which was to link young people with workplaces while they were still at school. The main thrusts of the strategy, however, were a revamped Industry Training Act, with a rationalisation of the number of ITOs, mechanisms for industry levies to finance the function of ITOs, and a partnership role for workers and their representatives. The flagship policy was the Modern Apprenticeships Programme (Labour Party, 1999).

The format chosen to 'revive' apprenticeship had parallels with the 'New Apprenticeships' scheme, introduced in Australia in 1998 (NCVER, 2001), and 'Modern Apprenticeships', introduced in the UK in 1995 (Maguire, 1998). In New Zealand, two group training schemes, for the electrical and the engineering industries, also provided ideas for the shape of the scheme (Clark, 2000). The detail of the Modern Apprenticeships policy was refined by a Modern Apprenticeships reference group, comprising employer, union, training provider and ITO representatives, and supported by Skill New Zealand staff (Industry Training Federation, 2000).

With the election of the Labour/Alliance coalition government, the 1999 election results gave a clear mandate for some gentle 'steering of the ship' by a centre left-government, and more specifically for the 'reintroduction' of apprenticeship.

Despite the increasing emphasis on tertiary education, the notion of 'getting a trade', via an apprenticeship, remains a strongly-held aspiration for many young people and their families. The word 'apprenticeship' embodies for many a potent mix of skill, respectability and career security, which news of the Modern Apprenticeships proposal very successfully tapped into. Little surprise, then, to hear the comments of the Prime Minister, Helen Clark, in March 2000:

What I know is that whenever I mentioned during the election campaign that Labour in government wanted to get more young people into apprenticeships, the applause nearly brought the house down. (Clark, 2000)

\section{Policy Details}

Modern Apprenticeships are administered by Skill New Zealand and:

- provide systematic, high quality workplace learning;

- are aimed primarily at sixteen to twentyone year olds;

- $\quad$ are based on a training agreement, signed off by employer and apprentice;

- lead to national qualifications at Levels 3 and 4 on the NQF;

- cover generic and specific skills;

- extend apprenticeship to non-traditional industries;

- complement existing education/training options (Skill New Zealand, 2001c) 
The essence of the programme is the appointment of Modern Apprenticeships Co-ordinators, who recruit and place apprentices, support and facilitate their training, and mentor them. It was hoped that the use of co-ordinators would remove some of the barriers to employers to taking on a young apprentice by reducing the costs and risks that employers face.

\section{Demographics}

The number of Modern Apprentices has increased rapidly since its inception, from less than 500 during the pilot phase to 3254 as at June 2002. Maori and Pacific peoples accounted for over 18 per cent of Modern Apprentices; however, barely five per cent (173) of apprentices were female. (Skill New Zealand, 2002e). A factor in this gender disparity may be that trainees remain concentrated in what could be considered 'traditional' apprenticeship industries (see Table 1), with these industries accounting for 66 per cent of Modern Apprentices as at September 2001, and 67 per cent as at June 2002. The primary industries, also with a tradition of structured industry training via the Primary Industry Cadet Scheme, accounted for a further 23 per cent of Modern Apprentices in each of the time periods (see Table 1). The May 2002 Modern Apprenticeships News celebrated the addition of Modern Apprenticeships in the tourism industry, and the expansion of training strands in the hospitality industry. A pilot scheme has also been established in office administration (Skill New Zealand, 2002c).

Table 1: Number of Modern Apprentices by Selected Industry: September 2001 \& June 2002 (Maharey, 2002; Skill New Zealand, 2001c)

$\begin{array}{llll}\text { Industry } & \text { September 2001 } & \text { Industry } & \text { June 2002 } \\ \text { Engineering } & 301 & \text { Building and Construction } & 536 \\ \text { Building and Construction } & 298 & \text { Engineering } & 515 \\ \text { Electrotechnology } & 166 & \text { Motor } & 373 \\ \text { Boating } & 94 & \text { Electrotechnology } & 282 \\ \text { Electricity Supply } & 71 & \text { Boating } & 165 \\ \text { Motor } & 62 & \text { Electricity Supply } & 132 \\ \text { Printing } & 61 & \text { Printing } & 86 \\ \text { Bakery } & 22 & \text { Bakery } & 94 \\ & \mathbf{1 0 7 5} & & \mathbf{2 1 8 3} \\ \text { (Percentage of total) } & (66 \%) & & (67 \%) \\ & & & 408 \\ \text { Forestry } & 251 & \text { Forestry } & 217 \\ \text { Agriculture } & 120 & \text { Agriculture } & 112 \\ \text { Horticulture } & 14 & \text { Horticulture } & \mathbf{7 3 7} \\ \text { (Percentage of total) } & \mathbf{3 8 5} & & (23 \%) \\ \text { All Other Industries } & 180 & & 334 \\ \text { Total Modern Apprentices } & \mathbf{1 6 4 0} & & \mathbf{3 2 5 4}\end{array}$

\section{Critique of the Modern Apprenticeships Programme}

The intent of Modern Apprenticeships is laudable. An increase in the number of young people in structured training helps develop the skill base of New Zealand, and provides the social benefit of a formalised transition route (without the young person accruing a student loan!). The appointment of co-ordinators relieves some of the stress and costs to an employer in having an apprentice, and ensures the apprentice makes appropriate progress. The reclamation of the term 'apprenticeship' not only revalidates an age-old method of training, but also has the potential to improve the status of the trades and industry in general, and of the work-based training route. Nevertheless, there are several concerns that may pose a threat to the sustainability of the programme.

At its core, Modern Apprenticeships is essentially a demand-driven policy, reliant on employers taking on apprentices. While the decision to train is not based wholly on economic factors, I would argue that the 
'training culture' has yet to be cemented sufficiently into New Zealand to counter the perennial problem of the cyclic nature of training. Some of the refinements to the traditional apprenticeship system, in particular, the use of co-ordinators, may blunt the imperative to contract training if the economy tightens. Modern Apprenticeships, however, has been introduced during a time of labour demand and skill shortages, and therefore remains to be proven as a policy that will lead to sustainable and even skill development.

\section{Funding}

As an election flagship policy, Modern Apprenticeships was well funded. The initial investment was $\$ 42.2$ million for the four years beginning mid-2000, which was to service a target number of 3000 Modern Apprentices by the end of 2002 (Maharey, 2000). In the 2002 budget, an extra $\$ 41$ million, spread over the following four years was announced, with the aim of doubling the number of Modern Apprentices to 6000 by December 2003 (Ministry of Education, 2002). Skill New Zealand expects to have 7500 Modern Apprentices by June 2006 (Skill New Zealand, 2002a). The bulk of this funding is paid to Modern Apprenticeships co-ordinating organisations, which are funded at a rate of around $\$ 2000$ per apprentice per year (Skill New Zealand, 2001a).

While the worth of this expenditure in providing administrative support to ease the employer's load, and to mentor the apprentice, is acknowledged, it must also be noted that none of this money is explicitly spent on actual training, or assessment, either on or off-job. The blanket nature of the rate also does not take into account differences in:

- Industry nature - industries with wellestablished training networks should logically require less support than those where the network must be developed by the co-ordinators;

- Industry size - economies of scale may be possible in industries where there are a larger number of apprentices;

- The nature of the co-ordinating organisation - this has an impact on the range of coordinating duties that are required. For example, it would be reasonable to expect that polytechnics would have to spend less time recruiting apprentices, as they have a catchment of young people who make contact with them. Conversely, a regional coordinating organisation, operating in a nontraditional industry, may have to expend enormous energy in attracting recruits.

These factors were identified in the evaluation of the Modern Apprenticeships pilots: "Some significant variations in co-ordinator cost structures were noted", as was the difficulty in establishing appropriate co-ordinator to apprentice ratios ${ }^{4}$ (Skill New. Zealand, 2001a, p.32).

The deadweight factor, that is, the extent to which a subsidy (albeit indirect in this case) is utilised without the targeted behaviour being changed, must also be assessed. Particularly in industries with well-established training networks, Modern Apprenticeships may be used to ease the administrative load of employers, rather than to create new training places. While Modern Apprenticeships does not provide the same sort of direct subsidy to employers as the discontinued Skill Start incentive ${ }^{5,}$ the paper-work associated with a trainee is such that the time saved through the use of a co-ordinator could amount to a significant saving for employers ${ }^{6}$. It is not argued that is necessarily a bad thing, but it does raise the question of the extent to which Modern Apprenticeships extends training:

We were never paid to do it [administer apprentices], now somebody else is getting paid to do what we were doing anyway! But there is no incentive for us to employ more people...

\section{(Employer, medium-sized electrical business).}

\section{Organisation}

Industry training in New Zealand is a complicated mystery to many employers, particularly those with small businesses. Modern Apprenticeships co-ordinators in the pilot phase found "a lack of knowledge among some employers about competency-based training and the

\footnotetext{
${ }^{4}$ Suggested ratios ranged from 1:30 to 1:60 (Skill New Zealand, 2001a).

${ }^{5}$ In July 1993, the government's concern about the scarcity of apprenticeship training prompted the offering of the Skill Start recruitment incentive. This was designed to encourage employers to take on and train young people aged between 16 and 21 years, and provided an incentive payment of $\$ 1000$ for recruitment of trainees in the target group. This payment was considered an acknowledgement of the high initial costs of taking on an apprentice or other trainee. Of the 2490 new apprentices recorded at February 1994, around 1870 were Skill Start Trainees. The government, however, was disappointed with the number of employers taking part in the scheme. It was considered unlikely that the target of 5000 places set for June 1994 would be reached. Skill Start was phased out in 1996, officially because of the 'sizeable' increase in the number of trainees, and the fact that it had been superceded by the Skill New Zealand Strategy (Education and Training Support Agency, 1996). An assessment of the scheme one year from its inception, however, pointed to the "significant deadweight cost" associated with the scheme (AGB McNair, 1994). The research showed that of the sample surveyed, 88 per cent of employers would have taken on the same number of apprentices regardless of the subsidy (AGB McNair, 1994).

${ }^{6}$ When Business New Zealand calculated the impact of the Labour/Alliance government's business policies on a typical medium-sized business over a three-year period, the savings made by taking on an Modern Apprentice (\$5500) were one of the few savings in a total cost to the business of various policies estimated at $\$ 26,398$ ("Businesses feeling the pain of new Government policies," 2002).
} 
National Qualifications framework, even in those industries which ha[d] a history of involvement in industry training" (Skill New Zealand, 2001a, p.14). While there is no doubt that the attraction of a Modern Apprenticeships Co-ordinator who would take over much of the paper-work is compelling, yet another route to industry qualifications may serve to obfuscate the process even further. Employers may find they are being solicited for training places by several organisations, and young people may favour one training route (because it includes the term 'apprenticeship'), when another equally legitimate route, resulting in the same qualification, is also offered.

Many of the activities performed by Modern Apprenticeships Co-ordinators were already attempted by ITOs, whose only constraint was lack of funding. In some industries, funding could perhaps be as effectively channeled through already established and proven industry organisations, without the addition of another layer of bureaucracy. It is interesting to observe, for example, that the Electrotechnology Industry Training Organisation (ETITO) has recently introduced five regional Apprentice Co-ordinators (ETITO, 2002). The Co-ordinators' main focus currently is the moderation of assessors, but the extension of this model to regular coordinating visits to all trainees (as opposed to only those on the Modern Apprenticeships programme) is not difficult to imagine.

While the establishment of a 'high value, prestigious education pathway' is one of the goals of the Modern Apprenticeships policy (and the value of this goal is not in dispute), it is of concern that the implementation of the policy could be unintentionally divisive. Trainees within the same firm may resent the extra resources available to a Modern Apprentice, if they are working towards a similar qualification. The distinction may also become apparent between trainees from different firms during offjob training. At the wider level, a 'high-skills, high-wage' economy requires the eventual upskilling of most of the workforce; does the Modern Apprenticeships programme privilege a smaller group of trainees at the expense of industry training as a whole?

The extension of the apprenticeship model (albeit 'modern') to industries without a history of structured training also raises some issues. For example, Modern Apprenticeships in the wool industry took longer than planned to establish: "although training to national standards ha[d] been occurring, the concept of a threeyear formalised commitment by the employer and young person [was] a new one given the transient nature of the workforce" (Skill New Zealand, 2001a, p.14). In both the United Kingdom and Australia, there has been a disparity in apprenticeship completion rates between the service and industrial sectors (Cleary, 2002; Ryan \& Unwin, 2001). This signposts the need for careful monitoring as Modern Apprenticeships in New Zealand expands into areas such as tourism and hospitality.

\section{Equity Issues}

The anticipated higher level of participation by women in Modern Apprenticeships expressed in the evaluation of the pilot schemes has yet to happen (Skill New Zealand, 2001a), with numbers static at around five per cent (Skill New Zealand, 2002e). As discussed previously, the range of industries represented in the programme at this time is clearly not conducive to increased numbers of female Modern Apprentices. It is not equitable, however, to rely on a broadening of industry range alone to increase the percentage of women. As signposted in the evaluation: "explicit strategies to ensure a fair representation of women will also be necessary" (Skill New Zealand, 2001a, p.28).

Pacific peoples are also under-represented in Modern Apprenticeships, comprising only two per cent of all Modern Apprentices as at June 2002, compared with six per cent in industry training in general (Skill New Zealand, 2002a). While Maori are well represented per capita, comprising 16 per cent of Modern Apprentices, the pattern found in general industry training, that is, the concentration of Maori in a small number of industries, is repeated. In the pilot phase of Modern Apprenticeships 47 per cent (42) of the 89 Maori Modern Apprentices were in the forestry industry (Skill New Zealand, 2001a). As at June 2002, around 70 per cent of the 536 Maori Modern Apprentices were concentrated in three core industries; engineering, building and construction, and forestry (Skill New Zealand, 2002a; 2002c).

Equity aims are mentioned in the statutory basis for Modern Apprenticeships, the Modern Apprenticeship Training Act 2000, and are made explicit in the evaluation process: "Skill New Zealand is currently working on participation strategies that not only involve a wider group of emerging industries, but that also seek to understand and address traditional gender segmentation in existing industries" (Skill New Zealand, 2002a, p.18). There is, however, an ongoing tension between the economic and social goals of industry training policies. Given that the quantity and quality of industry training is determined largely by the decisions of individual employers, the achievement of equitable outcomes relies upon policy that strikes the right balance between prescription and more subtle attempts to modify employers' decision-making processes.

\section{Areas for Further Research}

The Modern Apprenticeships programme is still in its infancy and there is clearly a need for ongoing monitoring and evaluation. At the quantitative level, cost-benefit analysis, and tracking of recruitment practices, completion rates and employment outcomes would be useful. Qualitative research could examine the experiences of both apprentices and employers. Research that explored the meanings ascribed to being a 'Modern Apprentice' would be of particular interest. 


\section{Conclusion}

The Modern Apprenticeships programme is at one level a pragmatic attempt to address both an important gap in the provision of training options for young people, and to alleviate skill shortages. At another level, it is an attempt to bolster the importance of skill acquisition for New Zealand as a whole; servicing the 'knowledge society'. Whether the programme is a sustainable means to achieve these ends is questionable, however, first because of some inconsistencies in the programme itself, and second, because historically, the best indicator of training provision in New Zealand has been the state of the economy. Currently, the economy is relatively buoyant and skilled workers in high demand; there appears to be little in Modern Apprenticeships, however, to counter the contraction in training that is likely to occur if economic conditions tighten.

\section{References}

AGB McNair. (1994). Assessment of the effectiveness of the Skill Start scheme. Wellington: AGB McNair.

Ashton, D. and Green, F. (1996). Education, training and the global economy. UK: Edward Elgar Publishing Ltd.

Building industry training at risk, say polytechs. (1998, 12 December). The Dominion, 2.

Businesses feeling the pain of new Government policies. (2002, 25 February). The New Zealand Herald.

Clark, H. (2000). Press Release: Modern Apprenticeships. Rt Hon Helen Clark Prime Minister Address to Port Nicholson Rotary Club Breakfast. Wellington: Newsroom.

Cleary, P. (2002, 19 August). Business failing the skills test [Website]. Financial Review. Retrieved 27 August, 2002, from the World Wide Web: http://afr.com/australia/2002/08/19/FFXIARS905 D

Department of Labour. (2001). Skills for a knowledge economy: A review of industry training in New Zealand. Wellington: Department of Labour.

Department of Statistics. (2002). Household labour force survey. Department of Statistics. Retrieved 6 May 2002, from the World Wide Web

Education and Training Support Agency. (1996). Annual report. Wellington: Education and Training Support Agency.

ETITO. (2002, July-August). Apprentice co-ordinators. ElectroLink, 30.

Gault, S. (1998, 1 June). Cuts in training spending hit motor-trade classes. The Daily News, 2.
Henderson, M. (1997, 27 April). Skills crisis warning bells were ignored. Sunday Star Times, 10.

Higgins, J. and Dalziel, P. (2002). Experience and suitability of job applicants: two policy issues from a survey of employers. Labour Market Bulletin, Special Issue 2000-2002, 151-171.

Industry Training Federation. (2000). Training Federation Update \#17, 17 April 2000. Wellington: Industry Training Federation.

Industry Training Federation. (2001). Industry Training Federation submission to "Skills for a Knowledge Economy: A Review of Industry Training". Wellington: Industry Training Federation.

Labour Party. (1999). 21st century skills: Labour's training strategy. Labour party. Retrieved 22 November, 1999, from the World Wide Web: www.labour.org.nz/InfoCentre1/Policies/Industry Trainingpol.html

Maguire, M. (1998). Modern Apprenticeships and employers. Journal of Vocational Education and Training, 50, 247-259.

Maharey, S. (2000). Modern Apprenticeships to close the skills gap (Media Statement). Wellington: Ministry of Education.

Ministry of Education. (2002). Vote Education 2002 Budget Initiatives Summary Table. Ministry of Education. Retrieved 26 August, 2002, from the World Wide Web: www.minedu.govt.nz/web/document page.cfm?id $\equiv 7151 \& \mathrm{p}=1041.7176$

National Advisory Council on the Employment of Women. (1994). Women's access to industry training. Wellington: NACEW.

NCVER. (2001). Group training apprenticeships and traineeships. Adelaide: Australia National Training Authority.

New Zealand Council of Trade Unions. (1993). Building a better workplace: Industry training policy (Policy Paper No. 10). Wellington: NZCTU.

New Zealand Council of Trade Unions. (1993). Building better skills. Wellington: NZCTU.

Piercy, G. (2002, May). A 'third way' in industry training: New Zealand's adaptation of selected British policies. Paper presented at the ESREA Conference, Roskilde, Denmark.

Rubens, P. (1996, 26 August). Telecomm industry faces staff shortage. The Dominion, 7.

Rushworth, P. (2001, September - October). PTE's or Poly's? ElectroLink, 24. 
Ryan, P. and Unwin, L. (2001). Apprenticeship in the British 'Training Market'. National Institute Economic Review, 178, 99-114.

Shelton, A. (1995, 16 August). Apprentice enrolment up but shortage remains. The Dominion, 3 .

Skill New Zealand. (2000a). Pathways to independence effective youth transitions. Wellington: Skill New Zealand.

Skill New Zealand. (2000b, April). Prime Minister launches Modern Apprenticeships. Skills.

Skill New Zealand. (2001a). Formative evaluation of the Modern Apprenticeships pilots. Wellington: Skill New Zealand.

Skill New Zealand. (2001b). Knowledge at work. Wellington: Skill New Zealand.

Skill New Zealand. (2001c). Modern Apprenticeships News. Wellington: Skill New Zealand.

Skill New Zealand. (2001d). Moving forward: Skills for the knowledge economy. Wellington: Skill New Zealand.
Skill New Zealand. (2002a). Brief to the incoming Minister of Education. Wellington: Skill New Zealand.

Skill New Zealand. (2002b). Industry training 2001. Wellington: Skill New Zealand.

Skill New Zealand. (2002c). Modern Apprenticeships News. Wellington: Skill New Zealand.

Skill New Zealand. (2002d, May 1). Vital statisitcs. Skill New Zealand. Retrieved 3 May 2002, from the World Wide Web: http://www.skillnz.govt.nz/new/vitalstatistics.htm

Skill New Zealand. (2002e, 9 August). Vital statistics [Website]. Skill New Zealand. Retrieved 27 August, 2002, from the World Wide Web: www.skillnz.govt.nz/new/vitalstatistics.htm

Walsh, P. and Brosnan, P. (1999). Redesigning industrial relations. = In St. John, S. (ed.), Redesigning the welfare state in New Zealand. Auckland: Oxford University Press. 